\section{Determination of Changes in the Dimensions of the Earth from Palæo- geographical Data}

EsSENTIALLY, there are two opinions concerning the volume of the Earth : (1) its volume is decreasing, that is, the Earth is shrinking; (2) its volume has remained practically constant during geological times.

Geological observations have clearly established that the volume of the hydrosphere has grown throughout the geological past; the increase, however, has not been more than about 4 per cent of the whole volume since early Cambrian times.

In the case of a shrinking Warth, the average depth of the oceans must have increased. As a consequence of the higher sea-level, the area of the continents covered by sea water should be increasing.

If the volume of the Earth has remained constant, the amount of water-covered areas is influenced only by crustal movements and, on average, it should oscillate about a constant value.

The problem of the constancy or otherwise of the volume of the Earth can be solved, therefore, on the basis of palæogeographical data. We have only to establish the amount of the areas covered by sea water in different geological ages : a definite increase in the average values means a shrinking Earth, whereas their constancy indicates that on balance the volume of the Earth has not appreciably changed.

Fig. 1 represents the water-covered continental areas computed from the palæogeographical maps of T. M. Strahow ; Fig. 2 is a similar diagram compiled from thirty-four palæogeographical maps recorded by $H$. Termier and G. Termier.

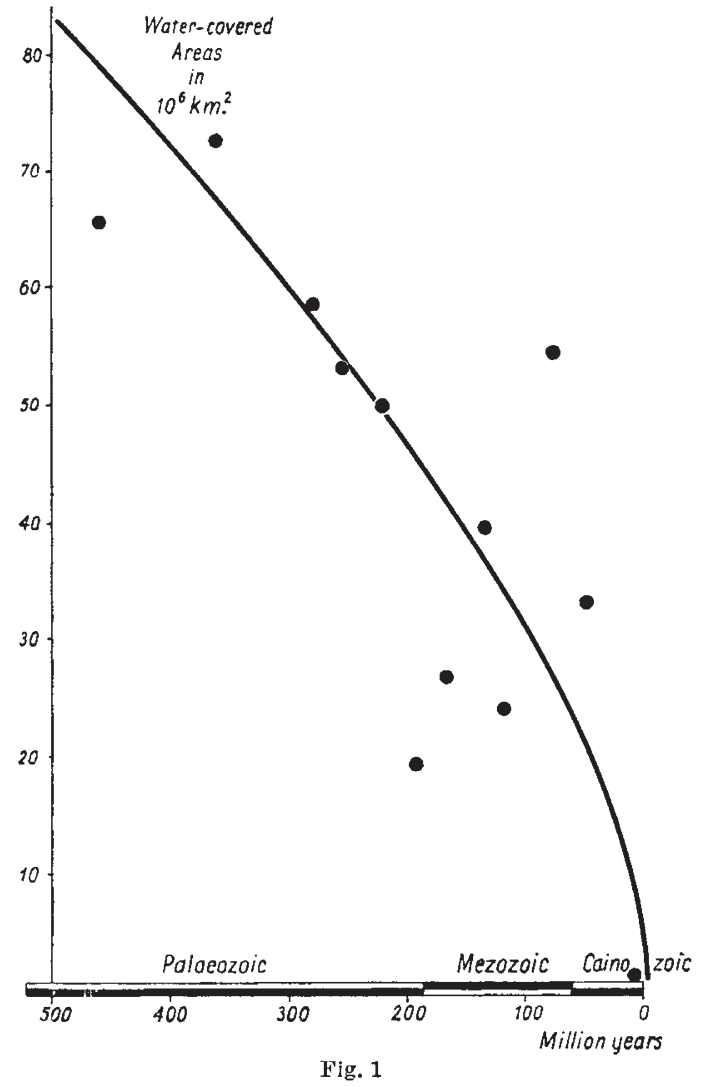

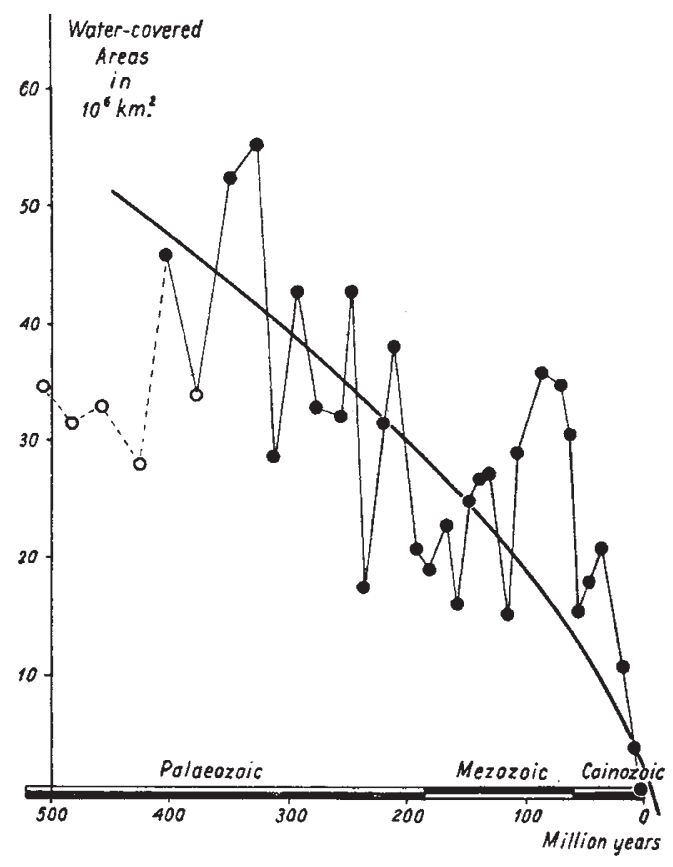

Fig. 2

In both diagrams the data plotted show a definite decrease in the course of the geological ages, indicating that there has been a cumulative increase of the radius of the Earth. Indeed, palæogeographical data provide evidence for the hypothesis that the Earth has expanded.

Figs. 1 and 2 can be used for giving the average rate of increase of the radius of the Earth, assuming that, on average, the hypsographic character of the Earth has remained the same since early Palæozoic times. Fig. 1 yields a radius increase of $0.66 \mathrm{~mm}$./year; Fig. 2, compiled from the Termiers' data, gives $0.4 \mathrm{~mm}$. /year.

It is concluded that the annual increase of radius, according to palæogeographical data, has averaged about $0.5 \mathrm{~mm}$./year during the past 500 million years.

Geophysical Institute,

L. EGYED

Eötvös L. University,

Budapest.

April 12.

\section{Magnetic Perturbation of the Lowest Triplet States of Aromatic Molecules by Dissolved Oxygen}

THE absorption spectrum of benzene in the region 2795-3650 A. has been measured by Miss Pitts ${ }^{1}$. She observed a shoulder at approximately $2900 \mathrm{~A}$. which has been tentatively assigned by Pariser $^{2}$ as a transition to a ${ }^{3} E_{1 u}$ state. Since it had been shown that oxygen dissolved in benzene absorbs strongly in this region ${ }^{3}$, the spectrum has been re-investigated. using pure benzene saturated with air or with nitrogen. A Beckman Model $D U$ spectrophotometer with 5-cm. silica cells was used, and the results obtained are shown in Fig. 1. No shoulder around $2900 \mathrm{~A}$. can be detected, although in most other respects the curve for air-saturated benzene is in reasonably good agreement with that of Miss Pitts. The absorption 